\title{
Silicon and aluminum in Bulgarian coals
}

\author{
Jordan Kortenski, Alexander Zdravkov \\ University of Mining and Geology "St. Ivan Rilski”, 1, Prof. Boyan Kamenov str., 1700 Sofia, Bulgaria; \\ E-mails: jordan_kortenski@abv.bg; alex_zdravkov@mgu.bg
}

\section{Силиций и алуминий в български въглища}

\author{
Йордан Кортенски, Александър Здравков
}

Минно-геоложки университет „Св. Иван Рилски“, ул. „Проф. Боян Каменов“№1, София 1700

\begin{abstract}
Резюме. Изследвано е присъствието и разпределението на $\mathrm{Si}$ и $\mathrm{Al}$ в 19 въглищни басейни и находища с възраст от Късен Карбон до Плиоцен, принадлежащи на 8 въглищни провинции в България. Въглищата са различен ранг - от лигнити до антрацити. Установява се, че присъствието и количеството на Si и Al във въглищата зависи от: i) концентрацията на елементите в скалите от бреговата ивица; ii) активността на повърхностното подхранване; iii) от киселинността на средата в древното торфено блато и iv) от наличието и състава на епигенетичната минерализация на въглищните пластове. Поради активно повърхностно подхранване, съдържанието на двата елемента е по-високо от средното за света за повечето въглища. Изключение правят Западномаришкият, Бургаският, Станянският, Орановският, Чукуровският и Пернишкият басейн, за които е характерно по-слабо повърхностно подхранване. В повечето басейни се установява силна положителна корелация на елементите с пепелното съдържание, което предполага техния преобладаващо неорганичен афинитет. Сравнително ниските стойности на отношението $\mathrm{Si} / \mathrm{Al}($ обикновено $<2$ ) и силната положителна корелация между тях $\left(\mathrm{r}_{\circ}>0,6\right)$ подсказват за доминиращата роля на глинестите минерали във въглищата като носител на изследваните елементи. Кварцьт е доминиращ единствено в Западномаришкия басейн. По-слаба корелация или негативна такава, в част от изследваните басейни (напр. Свогенски, Западномаришки, Софийски, Бургаски, Добруджански) подсказват за смесен или органичен афинитет на $\mathrm{Si}$ и $\mathrm{Al}$. Причина за този афинитет е освобождаването на елементите от глинестите минерали по време на торфо-/диагенезата и последващото образуване на комплекси елементо-органични съединения.
\end{abstract}

Ключови думи: български въглища, съдържание на Si и Al, привързаност към органично вещество.

Abstract. The presence and distribution of Si and Al in 19 Bulgarian coal basins and deposits, belonging to 8 coal provinces, were studied. Coals are of different rank (lignite to anthracite) and age (Late Carboniferous to Pliocene). The presence of both studied major elements depends strongly on: i) their concentration within the basin's provenance; ii) the extent of terrigenous supply; iii) environmental acidity during peat formation; and iv) the presence and composition of epigenetic mineralization within the coal seams. Because of the presumed abundant terrigenous supply, the concentrations of both $\mathrm{Si}$ and $\mathrm{Al}$ are higher than the world average for most of the studied coals. Exceptions are the Maritsa-West, Burgas, Staniantsi, Oranovo, Chukurovo and Pernik Basins, for which reduced terrigenous supply can be suggested. For most of the basins, both $\mathrm{Si}$ and $\mathrm{Al}$ demonstrate good positive correlation with the ash yields, thus arguing for predominant inorganic affinity. Relatively low $\mathrm{Si} / \mathrm{Al}$ ratios (typically $<2)$ and good positive correlation between $\mathrm{Si}$ and $\mathrm{Al}\left(\mathrm{r}_{\mathrm{o}}>0.6\right)$ imply the predominant role of the clay mineral assemblages as the main source of the elements in coal. Quartz is presumed to have dominant role only in Maritsa-West Basin. Poorer or negative correlations with the ash yields in part of the studied basins (i.e. Svoge, Maritsa-West, Sofia, Burgas and Dobrudzha Basins) suggest either mixed or predominantly organic affinity of the elements. Release of Si and $\mathrm{Al}$ from the clay minerals during the peat formation/diagenesis and subsequent formation of organo-metallic complexes is considered to responsible for such affinity.

Keywords: Bulgarian coals, concentration of Si and Al, organic affinity.

\section{Introduction}

The inorganic geochemistry of Bulgarian coals, coal ashes and solid waste products from thermoelectric power plants are widely reported (e.g. Eskenazy, 1978, 1987, 1992，1995，1999, 2009;
Kortenski et al., 1990; Vassilev et al., 1994, 1995, 1997, 2003, 2010; Vassilev, Vassileva, 1997, 1998; Eskenasy et al., 2001; Kortenski, Sotirov, 2001, 2002a, b, 2004; Kostova, Kortenski, 2002; Yossifova, 2007; Gouin et al., 2007; Yossifova et al., 2009; Kostova et al., 2011; Yossifova, Dimit- 
rova, 2013). Most of the publications, however, focus mainly on the concentration and geochemical behavior of the toxic and/or valuable trace elements. The occurrence and distribution of the major elements in coal is less studied (e.g. Eskenazy, $1972,1987,1989,1993)$. Sulfur is by far one of the most studied major elements (e.g. Kostova, 1999, 2002, 2005; Markova et al., 2007, 2008, etc.), because of its significant environmental impact. In a continuation of our previous attempts to characterize the occurrence, distribution and affinity of the major elements in Bulgarian coals (i.e. Kortenski, Zdravkov, 2019, 2020) here we summarize the data on the distribution of silicon and aluminum in 19 coal-bearing basins and deposits of different age and rank (Fig. 1).

\section{Geological settings}

\section{Svoge coal-bearing Province}

Svoge anthracite Basin. The basin represents an $\mathrm{E}-\mathrm{W}$ trending intermontane depression, filled with over 1800 m thick molasse-type sediments of Namurian $\mathrm{C}$ to Westphalian $\mathrm{B}-\mathrm{C}$ age. The basement and the provenance of the basin are composed of Ordovician to Devonian siltstones, shale, quartzite, sandstone, melasyenites and $\mathrm{K}$-alkaline quartz sienite. The basin fill is composed of 6 fining upward sequences (i.e. the Tsarichina, Svidnya, Dramsha, Svoge, Berovdol and Chibaovtsi Fms; Tenchov, 2007a), topped by either argillaceous rocks or coal. Between 7 and 17 anthracite seams (up to $1.2 \mathrm{~m}$ thick) are distributed throughout the basin.

\section{Dobrdzha coal-bearing Province}

Dobrudzha Basin. The coal-bearing Upper Carboniferous sediments (about $1600 \mathrm{~m}$ thick) formed in delta plain (Nikolov et al., 1988) or fluvial (Tenchov, 1993, 2005, 2007b) environments and overlie Lower Carboniferous (sandstone, siltstone and shale) and Devonian (marine limestone) rocks with an erosional unconformity (Tenchov, Koulakssuzov, 1972; Nikolov et al., 1988; Tenchov, 2005, 2007b). The succession is predominantly composed of irregularly alternating fine- to coarse-grained lithic sandstones, siltstones, shales, and coals, subdivided into four coal-bearing formations (i.e. the Mogilishte, Makedonka, Krupen and Gurkovo Fms), separated by three sandstone formations (i.e. the Vranino, Velkovo and Polyana Fms). Synchronous volcanic activity north-east of the basin (Nikolov et al., 1988) produced ash falls, which are marked by the presence of pyroclastic and volcanoclastic ma- terials in the Mogilishte, Makedonka and Gurkovo Fms. Many of the tuff layers are transformed into tonsteins (up to $20 \mathrm{~m}$ thick layers below some of the major coal seams (e.g. $1_{1}, \mathrm{~m}_{5}, \mathrm{p}_{3}$; Nikolov et al., 1988). The coal-bearing formations contain up to 86 bituminous coal seams, irregularly distributed within the profile.

\section{Balkan coal-bearing Province}

Balkan Basin. The basement and basin's provenance are composed of monzodiorite, amphibole-biotitic granodiorite, granite, tuff, fine-grained conglomerate, sandstone, siltstone, shale, limestone and dolomite of Paleozoic, Triassic, Jurassic and Early Cretaceous age (Kânčev et al., 1995). The Cenomanian coal-bearing siliciclastic sediments are subdivided into three informal units and contain up to 8 seams (up to $1.5 \mathrm{~m}$ thick) of bituminous coal.

Burgas Basin. The basin formed within the 15$20 \mathrm{~km}$ wide and N-S oriented Burgas syncline. The basement and catchment areas comprise Upper Cretaceous andesitic lava flows and tuffaceous rocks. These are overlain by over $450 \mathrm{~m}$ thick Upper Eocene (Priabonian) coal-bearing sediments, which are divided into two lithostratigraphic units, named respectively the Ravnets (siliciclastic sediments) and Mugris (massive marlstone) Fms (Juranov, 1992). Up to 9 sub-bituminous coal beds, formed under brackish conditions, are present at two levels within the Ravnets Fm. The lower one contains up to 4 coal beds with a maximum thickness of up to $4.50 \mathrm{~m}$, interbedded with thin layers of clays. The upper level is composed of two coal beds, named "A" and "B", among which only the topmost coal bed, i.e. "A", has greater thickness (avg. 2-3 m) and economic significance.

\section{Pernik coal-bearing Province}

Pernik Basin. The basement and the catchment areas are predominantly composed of conglomerate, sandstone, siltstone, marlstone, limestone, dolomite, sienite and monzonite with Paleozoic, Triassic and Early Cretaceous age (Zagorčev et al., 1994). The coal-bearing siliciclastic sediments are subdivided into 5 informal units and contain up to $5 \mathrm{sub}-$ bituminous coal seams with a total thickness of up to $20 \mathrm{~m}$.

Bobov Dol Basin. The basin formed within a N-NW to S-SE elongated graben structure (about $25-30 \mathrm{~km}$ long and $8-10 \mathrm{~km}$ wide). The graben infill comprises $1.0-1.5 \mathrm{~km}$ thick Oligocene to Lower Miocene siliciclastic sediments, subdivided into 6 formal units, covering the time span from Rupelian 


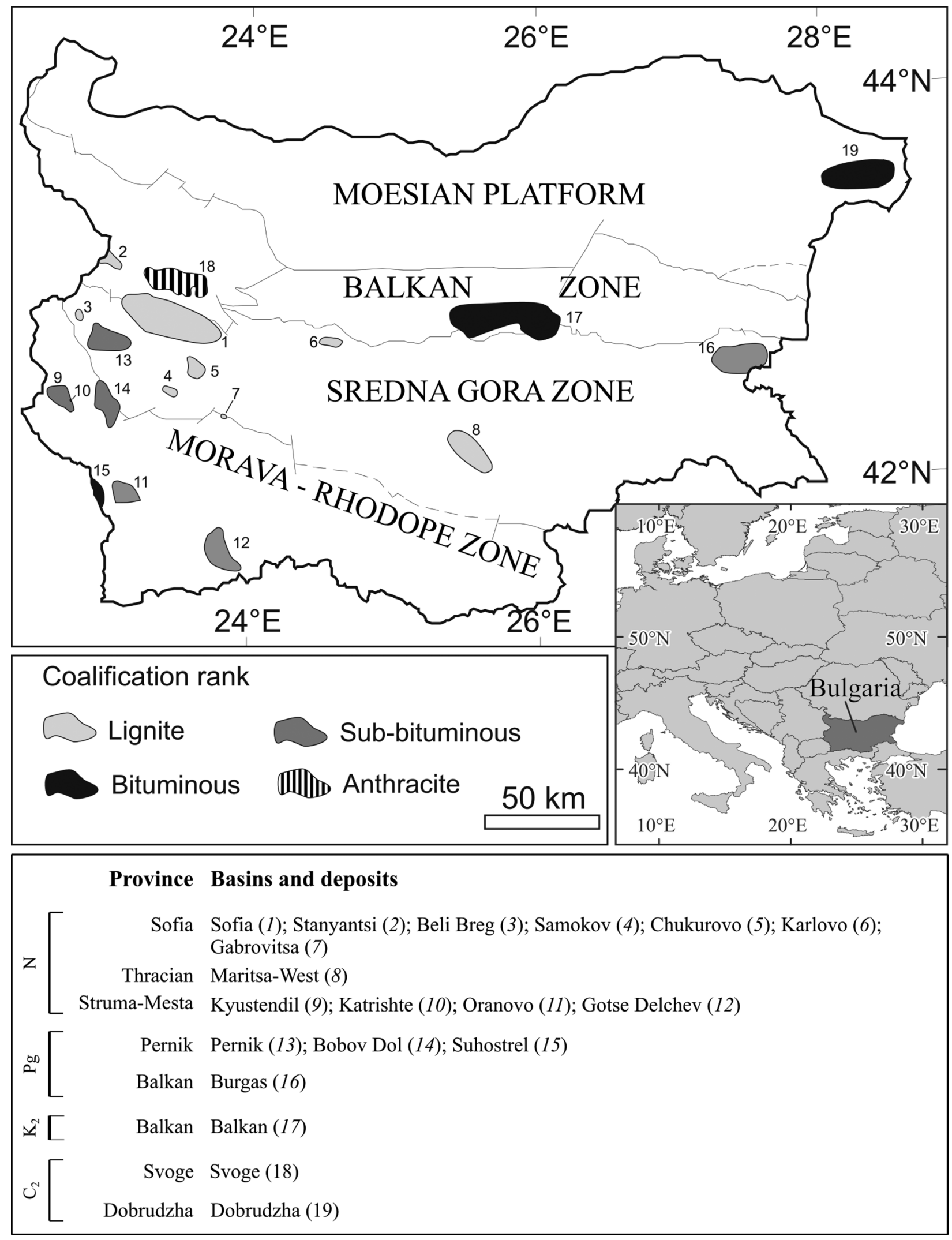

Fig. 1. Schematic map, showing the distribution of the studied coal basins and deposits Structural sub-division of Bulgaria after Dabovski et al. (2002)

Фиг. 1. Схематична карта с положението на изучаваните въглищни басейни и находища Структурната подялба на България е по Dabovski et al. (2002) 
to Late Egerian-Ottnangian (Vatsev, 2014, 2015). These overly denudated Vendian-Paleozoic metamorphic and magmatic rocks, Permian-Lower Triassic siliciclastic red beds, Middle to Upper Triassic carbonate rocks, Upper Cretaceous flysch and Upper Eocene flysch-like sandstone and mudstone alternation (Kamenov, 1959; Vatsev, 2014). Up to 14 seams of sub-bituminous coal, among which 6 (1.2-3.8 $\mathrm{m}$ thick) have wide spread occurrence, formed within the northern part of the graben.

Suhostrel Deposit. The deposit belongs to the southern parts of the N-S trending Padesh graben (Vatsev et al., 2011), filled with over $2000 \mathrm{~m}$ of coarse-graine molasse-type sediments. The basement and catchment areas are composed of Pre-Cambrian to upper Paleozoic and Lower to Middle Triassic rocks - diorite, amphibolite, shist, sandstone, conglomerate and limestone. The coal-bearing Suhostrel Fm. belong the to lower part of the Middle to Upper Eocene sedimentary fill and comprise up to 3 thin (up to $0.6 \mathrm{~m}$ ) bituminous coal seams.

\section{Struma-Mesta coal-bearing Province}

Kyustendil Basin and Katrishte deposit. The basin is superimposed over Proterozoic high-grade metamorphic rocks, Paleozoic gabbrodiorite and quartz diorite, Silurian limestone and shale, Triassic and Jurassic conglomerate, sandstone, dolomite and limestone, as well as Eocene sandstone and mudstone. The coal-bearing Miocene siliciclastic sediments ( $\sim 700 \mathrm{~m}$ thick) belong to the Spasovitsa, Skrinyano and Koilitsa Fms (Vatsev, Bonev, 1994). Single low-rank (lignite to sub-bituminous C (Kortenski, Sotirov, 2002b) coal seam with an average thickness of $5 \mathrm{~m}$ was discovered and prospected via drill-holes at the base of the Skrinyano Fm. at depth of over $300 \mathrm{~m}$. During the mid-1990s a small open-pit mine (i.e. Katrishte deposit) was operated along the eastern part of the basin, where the coal seam (4-12 m thick; Kortenski, Sotirov, 2002b) was detected at shallower depth.

Gotse Delchev Basin. The basement and surrounding areas are mainly composed of Proterozoic gneiss and schist, marble, granodiorite, and Paleogene conglomerate, sandstone, and siltstone. The lignite-bearing Pliocene sediments are sub-divided into 3 formal stratigraphic units (i.e. the Valevica, Baldevo and Nevrokop Fms; Vatsev, 1979). Up to 16 lignite seams formed, but only the lowermost one had economic significance. The other seams are characterized by small thickness and high ash yields.

Oranovo Basin. The basement and basin's provenance are composed of Pre-Cambrian amphibolite, biotite-amphibole gneiss, marble and shist, Paleozoic biotitic granite and granodiorite, and Upper
Cretaceous granite and quartz monzonite. The coalbearing Miocene siliciclastic sediments are subdivided into 5 formal lithostratigraphic units (i.e. the Drachevitsa, Oranovo, Duarska, Gradevska and Revalska Fms; Vatsev, 1991). Up to 16 sub-bituminous coal seams (1-8 $\mathrm{m}$ thick) are distributed within the Oranovo Fm.

\section{Sofia coal-bearing Province}

Sofia Basin. The basement and the provenance of the basin are composed of Permian and Triassic fluvial red beds, Jurassic and Lower Cretaceous carbonate, siliciclastic and argillaceous sediments, and Upper Cretaceous siliciclastic, carbonate, volcano-sedimentary and volcanic rocks (Yanev et al., 1995). The Neogene sedimentation commenced within the NW-SE oriented Sofia graben with the deposition of the Meotian clays, sands and sandstones of the informal variegated terrigenous formation (Kamenov, Kojumdzhieva, 1983). These are overlain by the sediments of the Sofia Group, consisting of the Gnilyane, Novi Iskar and Lozenets Fms (Kamenov, Kojumdzhieva, 1983). The lowermost Gnilyane Fm. is up to $100-150$ m thick and is composed of fining upwards Pontian terrigenous rocks (pebble to gravel breccia and conglomerates, sands and sandstones, siltstones and clays) covered by the Balsha Member. The latter represents thick lignite seam (avg. thickness $30 \mathrm{~m}$ ), which due to tectonic influences is locally thickened to $70-95 \mathrm{~m}$. At places, another high ash lignite seam (i.e., the Kremikovtsi seam) is presented underneath the Balsha Member. The following upwards middle Pontian to lower Dacian Novi Iskar Fm. is composed of monotonous (100-400 m thick) greyish finely laminated clays, with a thin interbed of whitish tuff. The rocks are overlain by the fluvial sediments of the Dacian-Romanian Lozenets Fm. (150-200 m thick), which towards the eastern part of the Sofia Basin contain another lignite bed, i.e. the Novihan bed. The latter is composed of carbonaceous shales and up to 10 thin lignite seams with limited distribution and very high ash yields (Kamenov, Kojumdzhieva, 1983). The Neogene lignite-bearing succession is covered by Pleistocene and Holocene alluvial and talus sediments.

Chukurovo Basin. The basin represents a NWSE oriented graben structure, situated to the southeast of Sofia Basin. The basement and provenance are composed of Proterozoic diabase and amphibole schist, Ordovician phyllite and schist, Permian to Middle Triassic siliciclastic red beds and tidal calcareous and dolomitic sandstones, Middle Jurassic limestones and Upper Cretaceous andesitic tuffs, argillaceous limestones and marlstones (Katskov, 
Iliev, 1993). The Neogene sedimentation commenced towards the eastern part of the graben with the deposition of up to $50 \mathrm{~m}$ thick fining upwards siliciclastic sediments (weakly lithified conglomerates, indurated sandstones, clays and carbonaceous clays) with 1 to $10 \mathrm{~m}$ thick lignite seam (i.e. the Gabra seam) on top. Because of active movements along thrusted faults from the eastern periphery of the graben, locally the beds are inclined or even overturned. Subsequently, sedimentation commenced with the deposition of Badenian-Volhynian (Palamarev, 1964) argillaceous sandstones with thin conglomerate and sandy claystone interbeds and the Chukurovo lignite seam. The latter is up to $40 \mathrm{~m}$ thick within the southern part of the basin, but splits into 12-18 thinner seams towards its norther part (Katskov, Iliev, 1993).

Staniantsi Basin. The basin represents small E-W oriented graben formed along the southern margin of Balkan structural zone. The basement and provenance are composed of Lower Triassic siliciclastic fluvial red beds, Middle Triassic limeand dolostones, and Jurassic and Upper Cretaceous limestones, locally with sandstone and marlstone interbeds (Haydutov et al., 1995). The basin infill overlie denudated pre-Neogene rocks and is subdivided into four formal lithostratigraphic units, the former three (i.e. the Dvechke, Belozem and Zainitsa Fms) united in Mazgosh-Staniantsi Group (Vatsev, 1999). Sedimentation commenced with the deposition of the 15-50 m thick sandy claystone and clayey sandstone of the Dvechke Fm. (Khersonian), followed upwards by up to $60 \mathrm{~m}$ thick carbonaceous claystone and marlstone of the Belozem Fm. (Khersonian-Pontian) with lignite seam (up to $20 \mathrm{~m}$ thick) at the base. The rocks are overlain by the sandy claystone (locally with clayey sandstone interbeds and caliche profiles) of the Zainitsa Fm. (35-60 m thick; Pontian-Dacian). Upper Pliocene to Pleictocene talus sediments $(50-80 \mathrm{~m}$ thick; the Stranya Fm.) overlie the lignite-bearing succession towards the northern margin of Staniantsi Basin.

Beli Breg Basin. The basin provenance is predominantly composed of Jurassic limestone and Upper Cretaceous marlstone, limestone, andesitic and latitic volcanic and pyroclastic rocks, tuffs and tephra flysch (Zagorcev et al., 1995). Because of the proximity to the large Sofia Basin, Zagorcev et al. (1995) consider the sedimentary infill of Beli Breg Basin to represent a lateral extension of the Lozenets Fm. from Sofia Basin. Sedimentation commenced with the deposition of up to $60 \mathrm{~m}$ thick clayey sandstones, locally interbedded by thin conglomerate beds at the bottom. These are overlain by up to $25 \mathrm{~m}$ thick lignite seam, followed by up to $40 \mathrm{~m}$ thick calcareous clays and marls. Another thin lignite seam is locally presented in the upper part of the succession. Fluvial channel and overbank siliciclastic sediments cover the Dacian aged lignitebearing succession.

Samokov Basin. The basin formed within the E-W oriented Palakaria graben, south of the large Sofia Basin. The basement and provenance are composed of Precambrian gneiss, schist and amphibolite, Ordovician diabase and phillyte, Upper Cretaceous siliciclastic and plutonic (diorite, quartz diorite, granodiorite) rocks (Zagorčev et al., 1994). The lignitebearing succession is subdivided into one informal and two formal lithostratigraphic units, as part of the Palakaria Group (Antimova, Kojumdgieva, 1991). The Neogene sedimentation commenced with the deposition of Pontian sands and conglomerates with sand interbeds (lower sand-conglomerate formation), followed upwards by Pontian-Dacian clays, sandstones, and up to $10 \mathrm{~m}$ thick lignite seam (the Alino Fm.), and upper Pliocene coarse-grained siliciclastic rocks and clays (the Relyovo Fm.). The lignite-bearing succession is overlain by fluvial and talus Quaternary deposits (Zagorčev et al., 1994).

Gabrovitsa deposit. The deposit is located within the central parts of the NW-SE oriented Kostenets graben. The latter is superimposed over Proterozoic mica and amphibole gneiss, mica schist, amphibolite and marble, and Paleogene siliciclastic rocks. The Pontian-Dacian lignite-bearing formation is composed of weakly lithified clayey sandstone, variegated clays and two lignite seams with thickness of up to 1.5-2m each (Dimitrova et al., 1990). The sediments are overlaid by Romanian brecciaconglomerate, sandstones and siltstones with total thickness of up to $560 \mathrm{~m}$.

Karlovo Basin. The lignite-bearing sediments deposited within the NW-SE oriented Karlovo graben. The basin provenance is comprised predominantly of Precambrian gneiss, schist, amphibolite, diabase, phyllite, upper Palaeozoic granite and granodiorite and Upper Cretaceous argillaceous limestone and marlstone (Rousseva et al., 1994). The MiocenePliocene basin infill is subdivided into two formal lithostratigraphic units, i.e., the Iganovo Fm. comprised of silty- to sandy clays with pebbly, sandy and clayey interbeds, covered by the lignite-bearing Moskovets Member (diatomaceous clays with 3 lignite seams). These are overlain by the Romanian siliciclastic deposits (pebbles, sands and clays) of the Karavelovo Fm. (Rousseva et al., 1994). Alluvial and talus sediments cover most of the graben.

\section{Thracian coal-bearing province}

Maritsa-West Basin. The basement and basin's provenance are composed of limestone of Middle Triassic, Late Eocene and Oligocene age, as well as Lower 
Oligocene sub-volcanic latite. The lignite-bearing Maritsa Formation is up to $450 \mathrm{~m}$ thick and is comprised of fluvio-lacustrine sediments of Miocene to Pliocene age (Kamenov, Panov, 1976; Bojanov et al., 1993). Two coal-bearing levels are recognized within the Maritsa Fm., but only the upper one, i.e., the 20-40 m thick Kipra Member had economic importance. The latter comprises four lignite seams with a total thickness of up to $5 \mathrm{~m}$, among which the Kipra and Havuzki seams are the thickest. The Kipra seam (1.75-2.9 $\mathrm{m}$ thick) comprises the biggest lignite reserves within the Maritsa-West basin.

\section{Material and methods}

For the purpose of the present study 912 coal samples and 75 carbonaceous shale samples from 19 coal basins, were studied. The high temperature ash yield was determined following standard procedure (ISO 17246:2010, n.d.). The ash was further mixed with lithium tetraborate and melted in platinum crucible at $1600{ }^{\circ} \mathrm{C}$. Subsequently, the alumino-silicate glass was dissolved in nitric acid (ISO 155872:2002, n.d.), and the concentrations of Si and $\mathrm{Al}$ were determined according (ISO 17294-1:2004, n.d.) and (ISO 17294-2:2016, n.d.) standards using ICP-VISTA-MPX SIMULTANEOUS CCD optical emission spectrometer.

The results were statistically evaluated and the Pearson's correlation coefficients $\left(r_{o}\right)$ between the studied major elements and ash yield were determined using Excel ${ }^{\mathrm{TM}}$ Data Analysis toolpack. Critical $r_{o}$ values were calculated based on two-tailed distribution, the sample size and alpha $=0.05$.

\section{Results and discussion}

Silicon. Most of the studied coals are characterized by silica concentrations in the range $4.0-10.8 \mathrm{wt} \%$ (Table 1). In comparison to the World average value (2.8 wt\%; Valković, 1983; Table 1), the established enrichment range from 1.4 to 3.9 times. Enrichment of Si exist also for the coal ashes, where the concentrations are 2.8-4.2 times higher than the Clarke value for claystones (Table 1). The coals from several basins (i.e. Maritsa-West, Stanyantsi, Chukurovo, Oranovo, Burgas and Pernik), however, are depleted in $\mathrm{Si}$ with concentrations up to 4 times lower than the World average (0.7-2.7 wt \%; Table 1). Notably, the carbonaceous shale ashes from these basins do not follow such depletion, thus suggesting that different supply mechanisms might have been responsible for the element input during peat (i.e. predominant groundwater supply) and shale (i.e. predominant terrigenous supply) formation.
Silicon is typically not considered to participate in the biological functions of higher plants. Recent advances in plant biology, however, indicate that Si uptake might increase plant's resistance against environmental stress and fungi (e.g. Luyckx et al., 2017; Frew et al., 2018). Although silicon is nonessential for plant growth, it is one of the most common inorganic constituents in plants. It is readily absorbed from soils and deposits within the plant tissues in the form of amorphous silica (opal) that ensures tissues strength and thus facilitates plant growth (Kabata-Pendias, 2010). Silicon uptake vary significantly from $<0.1 \%$ to $>10 \%$ (in some sedges, horsetails and diatoms) depending mostly on plant species (Kabata-Pendias, 2010). Therefore, the plant's inorganic constituents can have in particular cases pronounced impact on the concentration of $\mathrm{Si}$ in coals. However, since plant ash typically rarely exceed 2 wt\% (Misra et al., 1993; Kabata-Pendias, 2010), its influence on $\mathrm{Si}$ contents is presumed to be more pronounced only in very low ash coals. For medium to high ash coals like the studied herein, the main source of $\mathrm{Si}$ is presumed to be the siliciclastic input from basin's catchment areas (Beaton et al., 1991; Warwick et al., 1997; Spears, Zheng, 1999; Chen et al., 2014; Zhang et al., 2020). Quartz, feldspars and clay minerals, which are typical constituents in soils formed after felsic intrusive and metamorphic rocks, are the most common sources of the element. In particular cases, rhyolitic and tuffaceous rocks (Taylor et al., 1998), as well as direct input of opaline biogenic remains (Ward, 1992), can also be considered a significant source of Si. Within the peat-forming environment, the Si-bearing minerals can further be subjected to dissolution, depending on the physio-chemical conditions (i.e. $\mathrm{pH})$ and their relative stability under the particular environmental settings. The dissolved Si can further participate in plant growth or in mineralization of plant tissues. This is considered to be the most probable origin of opal in Maritsa-West coals (Kortenski, Dimitrov, 1990)

Considering the above discussion, the low $\mathrm{Si}$ concentration in basins with carbonate-dominated provenance (i.e. Maritsa-West, Stanyantsi, Chukurovo, and Pernik Basins) or basins subjected to marine transgression during peat formation (i.e. Burgas Basin), is not surprising. Within the individual coal provinces (i.e. Sofia, Pernik and Struma-Mesta Provinces), notable trends can be established. For example, Si concentration within the coals vary significantly, whereas carbonaceous shales are characterized by comparable silicon concentrations (Table 1). This fact suggests that different Si supply mechanisms (i.e. groundwater vs. terrigenous supply) might have been active during the peat and shale deposition. However, considering the low solubility 
Таблица 1

Средна концентращия на Si и Al във въглищуа, въглищна пепел и пепел от въглищни скали

Table 1

Average concentration of Si and Al in coal, coal ash and carbonaceous shale ash

\begin{tabular}{|c|c|c|c|c|c|c|c|c|c|c|c|c|}
\hline \multirow{3}{*}{$\begin{array}{l}\text { Basins, } \\
\text { deposits }\end{array}$} & \multirow{3}{*}{ 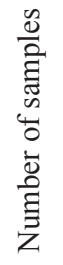 } & \multicolumn{6}{|c|}{ Average concentration (wt $\%)$ in: } & \multicolumn{4}{|c|}{ Pearson's correlation coefficients $\left(\mathrm{r}_{\mathrm{o}}\right)$} & \multirow{3}{*}{ 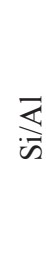 } \\
\hline & & \multicolumn{2}{|c|}{ coal } & \multicolumn{2}{|c|}{ coal ash } & \multicolumn{2}{|c|}{$\begin{array}{c}\text { carbonaceous } \\
\text { shale ash }\end{array}$} & \multirow{2}{*}{$\begin{array}{l}\frac{c}{\tilde{E}} \\
\dot{D} \\
\dot{D} \\
\dot{\bar{n}}\end{array}$} & \multirow{2}{*}{$\begin{array}{l}\frac{I}{\tilde{z}} \\
\mathbb{8} \\
\dot{D} \\
\dot{\nabla} \\
\bar{Z}\end{array}$} & \multirow{2}{*}{$\begin{array}{l}\dot{4} \\
\dot{\infty} \\
\dot{1} \\
\dot{n}\end{array}$} & \multirow{2}{*}{$\begin{array}{l}\widetilde{J} \\
: \stackrel{0}{0} \\
=0\end{array}$} & \\
\hline & & $\mathrm{Si}$ & $\mathrm{Al}$ & $\mathrm{Si}$ & $\mathrm{Al}$ & $\mathrm{Si}$ & $\mathrm{Al}$ & & & & & \\
\hline \multicolumn{13}{|c|}{ Thracian coal-bearing Province } \\
\hline Maritsa-West & 51 & 1.6 & 0.4 & 9.2 & 2.3 & 19.3 & 1.3 & +0.75 & -0.48 & -0.55 & $( \pm 0.28)$ & 4.0 \\
\hline \multicolumn{13}{|c|}{ Sofia coal-bearing Province } \\
\hline Beli Breg & 91 & 5.1 & 2.2 & 15.4 & 6.5 & 21.2 & 11.2 & +0.61 & +0.63 & +0.85 & $( \pm 0.21)$ & 2.3 \\
\hline Staniantsi & 38 & 2.1 & 1.5 & 6.1 & 4.2 & 25.3 & 14.1 & +0.93 & +0.87 & +0.98 & $( \pm 0.32)$ & 1.4 \\
\hline Sofia & 89 & 3.1 & 1.9 & 17.2 & 10.2 & 25.2 & 10.8 & +0.49 & +0.15 & +0.86 & $( \pm 0.21)$ & 1.6 \\
\hline Samokov & 31 & 7.7 & 3.5 & 22.3 & 10.2 & 28.2 & 12.3 & +0.52 & +0.32 & +0.73 & $( \pm 0.36)$ & 2.2 \\
\hline Karlovo & 23 & 4.4 & 2.5 & 22.0 & 12.7 & 31.0 & 18.2 & +0.54 & +0.41 & +0.88 & $( \pm 0.41)$ & 1.8 \\
\hline Chukurovo & 92 & 2.5 & 1.7 & 15.1 & 10.3 & 32.3 & 19.1 & +0.84 & +0.73 & +0.83 & $( \pm 0.20)$ & 1.5 \\
\hline Gabrovitsa & 46 & 4.2 & 3.0 & 15.0 & 10.5 & 24.0 & 16.2 & +0.69 & +0.48 & +0.81 & $( \pm 0.29)$ & 1.4 \\
\hline \multicolumn{13}{|c|}{ Struma-Mesta coal-bearing Province } \\
\hline Kyustendil & 39 & 4.0 & 2.8 & 12.2 & 8.3 & 20.2 & 13.2 & +0.44 & +0.42 & +0.70 & $( \pm 0.32)$ & 1.4 \\
\hline Oranovo & 61 & 0.7 & 0.3 & 7.5 & 2.8 & 25.4 & 7.4 & +0.83 & +0.71 & +0.57 & $( \pm 0.25)$ & 2.3 \\
\hline Gotse Delchev & 24 & 5.4 & 1.9 & 15.0 & 10.0 & 24.1 & 14.6 & +0.85 & +0.80 & +0.75 & $( \pm 0.40)$ & 2.8 \\
\hline Katrishte & 26 & 4.9 & 1.6 & 19.0 & 6.1 & 24.4 & 9.6 & +0.41 & +0.33 & +0.77 & $( \pm 0.39)$ & 3.1 \\
\hline \multicolumn{13}{|c|}{ Balkan coal-bearing Province } \\
\hline Balkan & 33 & 5.2 & 2.5 & 22.8 & 10.7 & 27.0 & 13.7 & +0.48 & +0.41 & +0.68 & $( \pm 0.34)$ & 2.1 \\
\hline Burgas & 28 & 0.9 & 1.5 & 7.7 & 9.2 & 20.5 & 10.1 & +0.59 & +0.27 & +0.84 & $( \pm 0.37)$ & 0.6 \\
\hline \multicolumn{13}{|c|}{ Pernik coal-bearing Province } \\
\hline Pernik & 35 & 2.7 & 1.0 & 15.0 & 5.8 & 26.1 & 9.2 & +0.52 & +0.49 & +0.65 & $( \pm 0.35)$ & 2.7 \\
\hline Bobov Dol & 48 & 7.3 & 4.4 & 22.2 & 13.2 & 25.7 & 15.4 & +0.88 & +0.59 & +0.55 & $( \pm 0.28)$ & 1.7 \\
\hline Suhostrel & 42 & 7.6 & 4.3 & 25.7 & 14.7 & 28.4 & 16.0 & +0.41 & +0.33 & +0.60 & $( \pm 0.30)$ & 1.8 \\
\hline \multicolumn{13}{|c|}{ Dobrudzha coal-bearing Province } \\
\hline Dobrudzha & 25 & 4.9 & 3.3 & 15.5 & 12.3 & 24.9 & 10.1 & +0.55 & -0.42 & -0.11 & $( \pm 0.40)$ & 1.5 \\
\hline \multicolumn{13}{|c|}{ Svoge coal-bearing Province } \\
\hline Svoge & 90 & 10.8 & 5.5 & 26.9 & 13.7 & 26.4 & 13.7 & -0.02 & -0.04 & +0.78 & $( \pm 0.21)$ & 2.0 \\
\hline World average* & & 2.8 & 1.0 & & & & & & & & & \\
\hline $\begin{array}{l}\text { Clarke values for } \\
\text { claystones** }\end{array}$ & & & & & & 7.3 & 8.0 & & & & & \\
\hline
\end{tabular}

* After Valković (1983)

** After Turekian, Wederpohl (1961) 
of Si, such hypothesis seems rather unlike. Instead, the amount of $\mathrm{Si}$ in coals is expected to vary significantly depending on the share of the siliciclastic input, whereas the predominant siliciclastic composition of the shales determines higher and comparable $\mathrm{Si}$ concentrations. More significant variations are observed only in the coals from the Sofia coal-bearing Province (Table 1), because of the differences in the lithological composition of the provenance. For Beli Breg Basin, the lowest detected herein Si concentration is predetermined by the predominance of carbonate rocks along the shoreline. Similarly, the low Si contents in Stanyantsi, Sofia and Gabrovitsa Basins, can also be considered a result of the presence of carbonate rocks within the catchment areas.

In higher rank and significantly fractured coals, the presence of epigenetic quartz mineralization, infilling fractures of different origin (i.e. fissures, desiccation and/or tectonic), can also be considered significant source of Si. Typical example is the Svoge anthracite, where the high Si concentration (i.e. $10.8 \mathrm{wt} \%$; Table 1) is related to epigenetic quartz veins, formed during the final (quartz) stage of mineral formation in that coal (Kortenski, Ilieva, 1991).

Based on the correlation between the $\mathrm{Si}$ and ash yields, the studied basins can be split into three groups. The first one comprises 9 basins (i.e. Maritsa-West, Beli Breg, Staniantsi, Sofia, Chukurovo, Gabrovitsa, Oranovo, Gotse Delchev and Bobov Dol Basins), in which silicon displays good to very good positive correlation with the ash yields $\left(\mathrm{r}_{\mathrm{o}}=\sim 0.5\right.$ up to $0.9 ; \mathrm{r}_{\mathrm{o}}>2 \mathrm{r}_{\mathrm{o}}$ critical; Table 1$)$ and argue for a predominant inorganic affinity of $\mathrm{Si}$ in that coals. Such affinity of Si is widely reported from various coals around the World (i.e. Beaton et al., 1991; Crowley et al., 1997; Warwick et al., 1997; Spears, Zheng, 1999; Liu et al., 2001; Zhao et al., 2017, 2020; Finkelman et al., 2019; Životić et al., 2019). Furthermore, Querol et al. (1997a, b, 2001a), Ward et al. (1999), Karayigit et al. (2000a, 2020) and Alastuey et al. (2001) accept a priori the exclusive relationship of $\mathrm{Si}$ with the clay minerals and use the correlation of the element with the alumino-silicate part of the ash to determine its mode of occurrence. Chen et al. (2014) and Zhang et al. (2020) report increased Si contents in the form of quartz as a result of the circulation of Si-rich hydrothermal solutions within the coal seams. The mineral form of $\mathrm{Si}$ in the studied basins is mainly associated with clay minerals and quartz, although a number of other predominantly terrigenous minerals (i.e. opal, anorthite, natrolite, stilbite, augite, orthoclase, albite, sericite, analcime, hypersthene, braunite, titanite, epidote, scapolite) have also been detected (e.g. Vassilev et al., 1994; Kostova et al., 1996; Kostova, Kortenski, 2002; Sotirov, Kortenski, 2002, 2004; Kostova, Zdravkov, 2007; Yossifo- va, 2007, 2014). Considering the relatively low values of the Si/Al ratio (1.5-2.8; i.e. Slansky, 1985) and the good positive correlation between $\mathrm{Si}$ and $\mathrm{Al}$ $\left(r_{\mathrm{o}}=0.55-0.98\right.$; Table 1) in those basins, however, indicate that quartz most probably plays secondary role as silicon source. Only for Maritsa-West lignite, the dominant role of quartz can be suggested by the high $\mathrm{Si} / \mathrm{Al}$ ratio (4.0) and the good negative correlation between the two elements (i.e. $\mathrm{r}_{\mathrm{o}}=-0.55$; Table 1). Furthermore, a clear predominance of the clay minerals over the low- to negligible amounts of terrigenous quartz, can be outlined as the main source of Si in the low-rank coals (except in Maritsa-West lignite). In higher-rank coals (i.e. the Balkan and Dobrudzha bituminous coals, and especially the Svoge anthracite), however, the occurrence of epigenetic quartz mineralization within cracks, can be considered as the most probable source of the element. Similar trend is also reported by Chen et al. (2014) and Zhang et al. (2020) for Chinese coal.

The second group of basins (i.e. Karlovo, Samokov, Kyustendil, Katrishte, Burgas, Pernik, Suhostrel, Balkan and Dobrudzha Basins), is characterized by poor positive correlation, as indicated by the relatively low $r_{o}$ values $\left(r_{o} \sim r_{o}\right.$ critical; Table 1$)$. Mixed organic/inorganic affinity with a slight predominance of the inorganic form of the element, can be suggested for these basins. Similarly like in the first group, the relatively low values of the $\mathrm{Si}$ / Al ratio (0.6-3.1) and the good positive correlation between $\mathrm{Si}$ and $\mathrm{Al}\left(\mathrm{r}_{\mathrm{o}}=0.60-0.88\right.$; Table 1$)$ argue for the major role on clay minerals as a source of $\mathrm{Si}$. Only for Katrishte coal, quartz can also be considered a source of the element. The data indicate that at least part of silicon exists in organic form. Considering the fact that the average Si content in plants is only about $0.07 \%$ (Voitkevich et al., 1983) the share of biogenic Si is most probably insignificant. However, although the organic acids within the peat mire would hardly affect most of the silicate minerals listed above, they can extract Si from the clay minerals. According to Tan (1975) small amount of silicon can be extracted into solution due to partial decomposition of clay minerals during humic acid treatment. The liberated Si can further participate in chemical reactions to form $\mathrm{Si}$ complexes with the organic acids (Yudovich, Ketris, 2002), which could explain the partial organic affinity of the element in this group of coal deposits.

The third group comprises only the Svoge anthracite, which displays no correlation between the $\mathrm{Si}$ concentrations and ash yields $\left(\mathrm{r}_{\mathrm{o}}=-0.02\right.$; Table 1$)$. This is a surprising observation, considering the high Si contents and the presence of epigenetic quartz veins in that coal. However, it should be noted that the inorganic matter there is mostly represented by syn- and epigenetic carbonate (siderite) and sulfide 
(pyrite) minerals, whereas Si-bearing (i.e. siliciclastic minerals+epigenetic quartz) minerals are rare (Kortenski, Ilieva, 1991), and therefore, have only minor share in the ash yield (Kortenski, Ilieva, 2000), which in turn reflects in the absence of significant correlation. Considering the high positive correlation between $\mathrm{Si}$ and $\mathrm{Al}$ (i.e. $\mathrm{r}_{\mathrm{o}}=0.78$ ), together with the low Si/Al ratio (Table 1), inorganic form of occurrence of $\mathrm{Si}$ (i.e. clay minerals) is also probable for that basin.

Aluminum. In coal ash the element's concentration vary from 2.3 to $14.7 \%$ (Table 1 ). The highest $\mathrm{Al}$ contents are detected in the ash from Bobov Dol and Suhostrel coal, as well as in Svoge anthracite. In comparison to the World's average Al contents in coal (Valković, 1983), the detected aluminum concentration is up to 5.5 times higher (Table 1). Exceptions are the Pernik coal, in which the $\mathrm{Al}$ content equals the World average, as well as the MaritsaWest and Oranovo coal, where the element shows significant depletion (Table 1). The carbonaceous shale ashes from the latter two basins also show Al depletion in comparison to the Clarke value for claystone (1.1 to 6.2 times), thus arguing for a limited siliciclastic input. For the rest of the basins, Al concentrations is enriched by a factor of 1.2 up to 2.4 (Table 1) in the carbonaceous shale ashes.

The good positive correlation between $\mathrm{Al}$ and ash yields in Beli Breg, Staniantsi, Chukurovo, Oranovo, Gotse Delchev and Bobov Dol coals $\left(\mathrm{r}_{0}>2 * \mathrm{r}_{\mathrm{o}}\right.$ critical; Table 1) argue for a predominant inorganic affinity of the element in those basins. Since aluminum is one of the most common chemical elements in Earth's crust, that is known to participate as a main or a secondary component in many silicate minerals, the mineral form of occurrence of the element is not surprising. Similar geochemistry of $\mathrm{Al}$ is also known from other coal around the World (i.e. Beaton et al., 1991; Querol et al., 1996; Crowley et al., 1997; Warwick et al., 1997; Spears, Zheng, 1999; Liu et al., 2001; Finkelman et al., 2019; Životić et al., 2019; Karayigit et al., 2020; Zhao et al., 2020). Moreover, Querol et al. (1997a, b, 2001a), Karayigit et al. (2000a, b), and Alastuey et al. (2001) accept a priori the exclusive relationship of Al with the clay minerals and use the correlation of the element with the alumino-silicate part of the ash in order to determine its mineral form of occurrence in coal. The mineralogical composition of the studied herein coal basins, also indicate that $\mathrm{Al}$ is mostly associated with the clay minerals, although accessory Al-bearing silicates (i.e. anorthite, natrolite, stilbite, augite, orthoclase, albite, sericite, analcime, epidote, alunite, natroalunite, spinel, halotrichite, etc.) have also been detected.

For the rest of the basins, however, the correlation between $\mathrm{Al}$ and the ash yields, although posi- tive, is either poor (i.e. $r_{0} \sim r_{0}$ critical in Karlovo, Gabrovitsa, Kyustendil, Pernik, Suhostrel and Balkan coal), or falls below the statistical significance (i.e. $\mathrm{r}_{\mathrm{o}}<\mathrm{r}_{\mathrm{o}}$ critical in Sofia, Samokov, Katrishte, Burgas and Svoge coal; Table 1). The latter suggests mixed organic/inorganic affinity of the element, although for part of the basins slight predominance of the inorganic form of Al can be suggested. Only in Maritsa-West and Dobrudzha coal the correlation is negative and argue for a predominantly organic affinity of the element. Although rarer, such affinity of Al is also reported. For example, Querol et al. (2001b) report between $78-95 \%$ of aluminum in some American coals has organic affinity. Ward (1992) also note that at least part of Al can participate in various organo-metallic compounds. This is probably mostly related to the increased solubility of $\mathrm{Al}$ in acidic environments (Kabata-Pendias, 2010), which might result in its release from the silicate minerals (i.e. Tan, 1975) and subsequent formation of complexes with the organic acids within the mire. Although Al is not considered to have significant biological functions, it is commonly detected in plants in concentrations ranging from few up to several thousand ppm (KabataPendias, 2010) and hence biological origin of the element cannot be ruled out. However, considering the average $\mathrm{Al}$ concentration in land plants is only $\sim 20 \mathrm{ppm}$ (Yudovich, Ketris, 2002), the contents of plant-derived Al in the studied coals are most probably negligible. Therefore, the presumed organic affinity of the element can mostly be considered to reflect the formation of stable organometallic humic and fulvic compounds within the acidic peat-forming environment.

\section{Conclusions}

Considering the above discussion, it can be summarized that the terrigenous input of silicate minerals was the main source of both $\mathrm{Si}$ and $\mathrm{Al}$ in the studied coal basins. Despite the fact that many silicate minerals were previously detected in Bulgarian coals, the clay minerals are considered the most important source of the elements, since the rest of the silicates are accessory and, therefore, cannot have significant effect on the total amount of the elements in coal. For that reason, the concentration of both $\mathrm{Al}$ and $\mathrm{Si}$ is lower in those basins where the clay mineral supply was limited, either due to dominance of carbonate rocks (i.e. Beli Breg, Staniantsi, Maritsa-West and Pernik Basins) or due to the absence of claystones (i.e. Oranovo Basin) within the catchment areas during peat formation. Environmental acidity is unlikely to significantly affect the elements' concentration, but is most responsible 
for the changes in the form of their occurrence in coal (i.e. inorganic vs. organic form). The epigenetic mineralization in some of the higher ranked coals (i.e. Balkan, Dobrudzha, Svoge) might be responsible for the increased Si contents, but have no pronounced effect on the concentration of aluminum, since the cracks are mostly filled by sulfides, carbonates and quartz. The epigenetic transforma- tion of the less stable syngenetic clay minerals (i.e. smectite, kaolinite, mixed-layer silicates, etc.) into illite or chlorite (Stach et al., 1982) could have influenced elemental concentrations in Suhostrel coal and Svoge anthracite, but it is far more likely that the higher $\mathrm{Al}$ contents in those basins is related to the predominance of argillaceous rocks within their catchment areas.

\section{References}

Alastuey, A., A. Jiménez, F. Plana, X. Querol, I. SuárezRuiz. 2001. Geochemistry, mineralogy, and technological properties of the main Stephanian (Carboniferous) coal seams from the Puertollano Basin, Spain. - Intern. J. Coal Geol., 45, 247-265; https://doi.org/10.1016/S01665162(00)00036-7.

Antimova, T., E. Kojumdgieva. 1991. The Neogene of the Palakaria basin (lithostratigraphic subdivision and geological evolution). - Paleont., Stratigr., and Lithol., 29, 45-59 (in Bulgarian with English abstract).

Beaton, A. P., F. Goodarzi, J. Potter. 1991. The petrography, mineralogy and geochemistry of a Paleocene lignite from southern Saskatchewan, Canada. - Intern. J. Coal Geol., 17, 117-148; https://doi.org/10.1016/0166-5162(91)90007-6.

Bojanov, I., Ž. Šiljafova., A. Goranov., M. Ruseva. 1993. Explanatory Note to the Geological Map of Bulgaria in Scale 1:100 000. Dimitrovgrad Map Sheet. Sofia, Committee of Geology and Mineral Resources, Geology \& Geophysics Corp., 67 p. (in Bulgarian with English abstract).

Chen, J., G. Liu, H. Li, B. Wu. 2014. Mineralogical and geochemical responses of coal to igneous intrusion in the Pansan Coal Mine of the Huainan coalfield, Anhui, China. - Intern. J. Coal Geology, 124, 11-35; https://doi. org/10.1016/j.coal.2013.12.018.

Crowley, S. S., P. D. Warwick, L. F. Ruppert, J. Pontolillo. 1997. The origin and distribution of HAPs elements in relation to maceral composition of the A1 lignite bed (Paleocene, Calvert Bluff Formation, Wilcox Group), Calvert mine area, east-central Texas. - Intern. J. Coal Geol., 34, 327-343; https://doi.org/10.1016/S0166-5162(97)00029-3

Dabovski, C., I. Boyanov, K. Khrischev, T. Nikolov, I. Sapunov, Y. Yanev, I. Zagorchev. 2002. Structure and Alpine evolution of Bulgaria. - Geologica Balc., 32, 2-4, 9-15.

Dimitrova, R., N. Katzkov. 1990. Explanatory Note to the Geological Map of Bulgaria 1:100 000. Velingrad Map Sheet. Sofia, Committee of Geology, Enterprise of Geophysical Prospecting and Geological Mapping, 52 p. (in Bulgarian with English abstract).

Eskenazy, G. M. 1972. Some aspects of the geochemistry of titanium during coal formation. - Ann. Univ. de Sofia, Fac. géol. et géogr., 65, 1-géol., 177-199 (in Russian with English abstract).

Eskenazy, G. M. 1978. Rare-Earth elements in some coal basins of Bulgaria. - Geologica Balc., 8, 2, 81-88.

Eskenazy, G. M. 1987. Rare earth elements and yttrium in lithotypes of Bulgarian coals. - Organic Geochem., 11, 83-89; https://doi.org/10.1016/0146-6380(87)90030-1.

Eskenazy, G. M. 1989. Phosphorus in some coal in Bulgaria. Rev. Bulg. Geol. Soc., 50, 3, 72-83 (in Russian).
Eskenazy, G. M. 1992. On the geochemistry of gold in Bulgarian coals. - Geologica Balc., 22, 1, 47-58.

Eskenazy, G. M. 1993. Geochemistry of manganese in Bulgarian coals. - Ann. Univ. de Sofia, Fac. géol. et géogr., 85, 1-géol., 31-52 (in Bulgarian with English abstract).

Eskenazy, G. M. 1995. Geochemistry of arsenic and antimony in Bulgarian coals. - Chemical Geol., 9, 239-253; https:// doi.org/10.1016/0009-2541(94)00091-L.

Eskenazy, G. 1999. Aspects of the geochemistry of rare earth elements in coal: an experimental approach. - Intern. J. Coal Geol., 38, 285-295; https://doi.org/10.1016/S01665162(98)00027-5.

Eskenazy, G. M. 2009. Trace elements geochemistry of the Dobrudza coal basin, Bulgaria. - Intern. J. Coal Geol., 78, 192-200; https://doi.org/10.1016/j.coal.2009.01.005.

Eskenasy, G., S. V. Vassilev. 2001. Geochemistry of chlorine and bromine in Bulgarian coals. - Rev. Bulg. Geol. Soc., $62,1-3,37-46$

Finkelman, R. B., S. Dai, D. French. 2019. The importance of minerals in coal as the hosts of chemical elements: A review. - Intern. J. Coal Geol., 212; https://doi.org/10.1016/j. coal.2019.103251.

Frew, A., L. A. Weston, O. L. Reynolds, G. M. Gurr. 2018. The role of silicon in plant biology: a paradigm shift in research approach. - Annals of Botany, 121, 1265-1273; https://doi. org/10.1093/aob/mcy009.

Gouin, J., C. Lerouge, Y. Deschamps, F. Laggoun-Defarge, M. Yossifova, Y. Yanev. 2007. Petrological and geochemical characterization of Ge-bearning coals from eastern Rhodopes, Bulgaria. - Digging Deeper, 9th Biennial SGA Meeting. August 20-23, 2007, Dublin, Ireland, 2, $1521-1524$

Haydutov, I., S. Yanev, D. Tronkov, D. Tchounev, I. Sapunov, P. Tchoumatchenco, T. Tzankov, T. Nikolov, R. Dimitrova. 1995. Explanatory Note to the Geological Map of Bulgaria on Scale 1:100 000. Pirot Map Sheet. Sofia, Committee of Geology and Mineral Resources, Geology \& Geophysics Corp., 78 p. (in Bulgarian with English abstract).

ISO 15587-2:2002. n.d. Water quality - Digestion for the determination of selected elements in water - Part 2: Nitric acid digestion.

ISO 17246:2010. n.d. Coal - Proximate analysis.

ISO 17294-1:2004. n.d. Water quality - Application of inductively coupled plasma mass spectrometry (ICP-MS) - Part 1: General guidelines.

ISO 17294-2:2016. n.d. Water quality - Application of inductively coupled plasma mass spectrometry (ICP-MS) - Part 2: Determination of selected elements including uranium isotopes. 
Juranov, S. 1992. Stratigraphy of the Eocene series in the Burgas district. - Rev. Bulg. Geol. Soc., 53, 2, 47-59 (in Bulgaria with English abstract).

Kabata-Pendias, A. 2010. Trace Elements in Soils and Plants. 4th ed. Boca Raton, Fl, CRC Press, 534 p.; https://doi. org/10.1016/j.coal.2009.01.005.

Kamenov, B. 1959. Die Geologie des Bobowdoler Braunkohlenbeckens. - Ann. Direct. génér. des recherches géol., Ser. A, 8, 1-26 (in Bulgarian with German and Russian abstracts).

Kamenov, B., E. Kojumdzhieva. 1983. Stratigraphy of the Neogene in Sofia Basin. - Paleont., Stratigr., and Lithol., 18, 69-85 (in Bulgarian with English abstract).

Kamenov, B., G. Panov. 1976. Geological correlation between coal beds of the Maritza-West and Maritza-East mines in the Maritza basin. - Petroleum and Coal Geology, 4, 60-71 (in Bulgarian with English abstract).

Kânčev, I., T. Nikolov, N. Ruskova, V. Milanova. 1995. Explanatory Note to the Geological Map of Bulgaria on Scale 1:100 000. Tvardica Map Sheet. Sofia, Committee of Geology and Mineral Resources, Geology \& Geophisics Corp., 139 p. (in Bulgarian with English abstract).

Karayigit, A., D. Spears, C. Booth. 2000a. Distribution of environmental sensitive trace elements in the Eocene Sorgun coals, Turkey. - Intern. J. Coal Geol., 42, 297-314; https:// doi.org/10.1016/S0166-5162(99)00044-0.

Karayigit, A., D. Spears, C. Booth. 2000b. Antimony and arsenic anomalies in the coal seams from the Gokler coalfield, Gediz, Turkey. - Intern. J. Coal Geol., 44, 1-17; https:// doi.org/10.1016/S0166-5162(99)00046-4.

Karayigit, A. I., M. Atalay, R. G. Oskay, P. Córdoba, X. Querol, Y. Bulut. 2020. Variations in elemental and mineralogical compositions of Late Oligocene, Early and Middle Miocene coal seams in the Kale-Tavas Molasse subbasin, SW Turkey. - Intern. J. Coal Geol., 218; https://doi. org/10.1016/j.coal.2019.103366.

Katskov, N., K. Iliev. 1993. Explanatory Note to the Geological Map of Bulgaria in Scale 1:100 000. Ihtiman Map Sheet. Sofia, Committee Geology and Mineral Resources, Geology \& Geophysics Corp., 63 p. (in Bulgarian with English abstract)

Kortenski, J., Y. Dimitrov. 1990. Mineral composition of the inorganic matter of the coal from West-Maritsa Basin. Ann. High. Inst. Mining and Geol., 36, 1- Geol., 169-177 (in Bulgarian with English abstract).

Kortenski, J., I. Ilieva. 1991. Minerals forms of presence and stages of mineral formation at the coal of Svoge anthracite basin. - Ann. Univ. Mining and Geol., 37, 1-Geol., 233248 (in Bulgarian with English abstract).

Kortenski, J., I. Ilieva. 2000. Distribution of major elements in the coal from "Chibaovtsi-Dramsha" deposit - Svoge anthracite Basin. - Rev. Bulg. Geol. Soc., 61, 1-3, 101-110 (in Bulgarian with English abstract).

Kortenski, J., A. Sotirov. 2001. Chalcophile elements in some Bulgarian coals. - Geologica Balc., 30, 3-4, 77-88.

Kortenski, J., A. Sotirov. 2002a. Trace and major element content and distribution in Neogene lignite from the Sofia Basin, Bulgaria. - Intern. J. Coal Geol., 52, 63-82; https://doi. org/10.1016/S0166-5162(02)00133-7.

Kortenski, J., A. Sotirov. 2002b. Occurrence and Distribution of Environmentally Hazardous Elements in the Katrishte Lignite Bed, Strouma-Mesta Province, Bulgaria. - Environmental Geosci., 9, 191-199; https://doi.org/10.1046/ j.1526-0984.2002.94003.x.

Kortenski, J., A. Sotirov. 2004. Occurrence and distribution of the siderophile elements in some Bulgarian coals. - Geologica Balc., 84, 3-4, 71-88.
Kortenski, J., A. Zdravkov. 2019. Alkaline and alkaline earth major elements in lignite from the Sofia coal province, Bulgaria. - Rev. Bulg. Geol. Soc., 80, 2, 5-14.

Kortenski, J., A. Zdravkov. 2020. Factors controlling the occurrence and distribution of iron in Bulgarian coals. - Rev. Bulg. Geol. Soc., 81, 2, 27-40; https://doi.org/10.52215/ rev.bgs.2020.81.2.3.

Kortenski, J., I. Ilieva, P. Popova. 1990. Trace elements in coal seams of the Svoge anthracite basin. - Geologica Balc., 20, $4,63-77$.

Kostova, I. J. 1999. Distribution and origin of sulphur in coals from Maritsa East Basin. - Ann. Univ. Mining and Geol., 42, 1-Geol., 69-74 (in Bulgarian with English abstract).

Kostova, I. J. 2002. Genetic factors related to the accumulation and stratigraphic distribution of sulphur in coal from the Pernik and Balkan basins. - Ann. Univ. de Sofia, Fac. géol. et géogr., 95, 1-géol., 67-85 (in Bulgarian with English abstract).

Kostova, I. J. 2005. Sulphur contents in coals from some Bulgarian basins. - Minno Delo i Geologiya J., 9, 40-44 (in Bulgarian).

Kostova, I. J., J. Kortenski. 2002. Inorganic composition of lignite from the Maritza East Basin. - C. R. Acad. Bulg. Sci., $55,10,49-54$.

Kostova, I., A. Zdravkov. 2007. Organic petrology, mineralogy and depositional environment of the Kipra lignite seam, Maritza-West basin, Bulgaria. - Intern. J. Coal Geol., 71, 527-541; https://doi.org/10.1016/j.coal.2006.06.006.

Kostova, I., O. Petrov, J. Kortenski. 1996. Mineralogy, geochemistry and pyrite content of Bulgarian subbituminous coals, Pernik Basin. - In: Gayer, R., I. Harris (Eds). Coalbed Methane and Coal Geology, Geological Society London Special Publication, 109, 301-314; https://doi.org/10.1144/ GSL.SP.1996.109.01.22.

Kostova, I. J., C. G. Vassileva, J. C. Hower, M. Mastalerz, S. V. Vassilev, N. Nikolova. 2011. Mercury in coals and fly ashes from "Republika" and "Bobov Dol" thermoelectric power plants. - C. R. Acad. Bulg. Sci., 64, 2, 253-262.

Liu, D., Q. Yang, D. Tang, X. Kang, W. Huang. 2001. Geochemistry of sulfur and elements in coals from the Antaibao surface mine, Pingshuo, Shanxi Province, China. - Intern. J. Coal Geol., 46, 51-64; https://doi.org/10.1016/S01665162(00)00040-9.

Luyckx, M., J.-F. Hausman, S. Lutts, G. Guerriero. 2017. Silicon and plants: Current knowledge and technological perspectives. - Frontiers in Plant Sci., 8; https://doi. org/10.3389/fpls.2017.00411

Markova, K., J. Kortenski, D. Sumnaliev, G. Shopov, D. Thzvetkova. 2007. Sulphur in Chukurovo and Beli Breg Basins coals. - J. Univ. Chem. Techn. and Metallurgy, 42, 21-28.

Markova, K., J. Kortenski, D. Sumnaliev, G. Shopov, B. Mitovski. 2008. Sulphur in coals from the Sofia and Stanyantsi basins. - J. Univ. Chem. Techn. and Metallurgy, 43, 309-314.

Misra, M. K., K. W. Ragland, A. J. Baker. 1993. Wood ash composition as a function of furnace temperature. - Biomass and Bioenergy, 4, 103-116; https://doi.org/10.1016/09619534(93)90032-Y.

Nikolov, Z., E. Stefanova, Y. Tenchov., K. Popova, A. Popov, T. Dimitrova, G. Manev, V. Parashkevova, I. Ivanov, J. Yanakiev, R. Peeva. 1988. Geology of Dobrudzha Coal Basin. Sofia, Tehnika, 170 p. (in Bulgarian).

Palamarev, E. 1964. Palaeobotanical studies of Chukurovo coal basin. - Proceedings of the Botanical Institute, BAS, 13, 5-80 (in Bulgarian with Russian abstract).

Querol, X., L. Cabrera, W. Pickel, A. López-Soler, H. W. Hagemann, J. L. Fernández-Turiel. 1996. Geological con- 
trols on the coal quality of the Mequinenza subbituminous coal deposit, northeast Spain. - Intern. J. Coal Geol., 29, 67-91; https://doi.org/10.1016/0166-5162(95)00009-7.

Querol, X., A. Alastuey, A. López-Soler, F. Plana, J. L. Fernández-Turiel, R. Zeng, W. Xu, X. Zhuang, B. Spiro. 1997a. Geological controls on the mineral matter and trace elements of coals from the Fuxin basin, Liaoning Province, northeast China. - Intern. J. Coal Geol., 34, 89-109; https://doi.org/10.1016/S0166-5162(97)00014-1.

Querol, X., M. K. G. Whateley, J. L. Fernández-Turiel, E. Tuncali. 1997b. Geological controls on the mineralogy and geochemistry of the Beypazari lignite, central Anatolia, Turkey. - Intern. J. Coal Geol., 33, 255-271; https://doi. org/10.1016/S0166-5162(96)00044-4.

Querol, X., A. Alastuey, X. Zhuang, J.. Hower, A. LopezSoler, F. Plana, R. Zeng. 2001a. Petrology, mineralogy and geochemistry of the Permian and Triassic coals in the Leping area, Jiangxi Province, southeast China. - Intern. J. Coal Geol., 48, 23-45; https://doi.org/10.1016/S01665162(01)00036-2.

Querol, X., Z. Klika, Z. Weiss, R.. Finkelman, A. Alastuey, R. Juan, A. López-Soler, F. Plana, A. Kolker, S. R. Chenery. 2001b. Determination of element affinities by density fractionation of bulk coal samples. - Fuel, 80, 83-96; https:// doi.org/10.1016/S0016-2361(00)00059-4.

Rousseva, M., D. Angelova, T. Tzankov. 1994. Explanatory Note to the Geological Map of Bulgaria on Scale 1:100 000. Karlovo Map Sheet. Sofia, Committee of Geology and Mineral Resources, Geology \& Geophysics Corp., 60 p. (in Bulgarian with English abstract).

Slansky, J. M. 1985. Geochemistry of high-temperature coal ashes and the sedimentary environment of the New South Wales coals, Australia. - Intern. J. Coal Geol., 5, 339-376; https://doi.org/10.1016/0166-5162(85)90002-3.

Sotirov, A., J. Kortenski. 2002. Petrology and mineralogy of the coal from the Katrishte deposit, Bulgaria. - C. R. Acad. Bulg. Sci., 55, 6, 73-78.

Sotirov, A., J. Kortenski. 2004. Petrography of the coal from the Oranovo-Simitli basin, Bulgaria and indices of the coal facies. - Intern. J. Coal Geol., 57, 71-76; https://doi. org/10.1016/j.coal.2003.08.004.

Spears, D., Y. Zheng. 1999. Geochemistry and origin of elements in some UK coals. - Intern. J. Coal Geol., 38, 161179; https://doi.org/10.1016/S0166-5162(98)00012-3.

Stach, E., M.-T. Mackowsky, M. Teichmuller, G.H. Taylor, D. Chandra, R. Teichmuller. 1982. Stach's Textbook of Coal Petrology. Second. ed., Berlin, Stuttgart, Gebrueder Borntraeger, $535 \mathrm{p}$.

Tan, K. H. 1975. The catalytic decomposition of clay minerals by complex reaction with humic and fulvic acid. - Soil Sci., 120, 188-194; https://doi.org/10.1097/00010694197509000-00005.

Taylor, G. H., M. Teichmuller, A. Davis, C. F. K. Diessel, R. Littke, P. Robert. 1998. Organic Petrology. Berlin, Stuttgart, Gebruder Borntraeger, 704 p.

Tenchov, Y. 1993. Sedimentation and erosion during the Late Carboniferous in the Dobrudza Coal Field (North-East Bulgaria). - Geologica Balc., 23, 2, 3-18.

Tenchov, Y. 2005. Early Westphalian sediments of Dobrudzha Coalfield (NE Bulgaria) - an interpretation of their stratigraphy and sedimentation conditions. - Zeitschrift der Deutschen Gesellschaft für Geowissenschaften, 156, 467480; https://doi.org/10.1127/1860-1804/2005/0156-0467.

Tenchov, Y. 2007a. The Carboniferous of Svoge Coalfield (Bulgaria). - Geologica Balc., 36, 1-2, 1-15.

Tenchov, Y. 2007b. Late Westphalian and early Stephanian sediments of the Dobrudzha Coalfield, NE Bul- garia. - Geol. Mag., 144, 497; https://doi.org/10.1017/ S0016756807003445.

Tenchov, Y., G. Koulakssuzov. 1972. Lithostratigraphy of the Late Carboniferous in Dobrudzha Coal Basin. - Bull. Geol. Inst., Ser. Stratigr. and Lithol., 21, 41-62 (in Bulgarian with English abstract).

Turekian, K. K., K. H. Wedepohl. 1961. Distribution of the elements in some major units of the Earth's crust. - Bull. Geol. Soc. Am., 72, 181-263; https://doi.org/10.1130/00167606(1961)72[175:DOTEIS]2.0.CO;2.

Valković, V. 1983. Trace Elements in Coal. CRC Press, Inc., Raton, Fla., 210 p.

Vassilev, S. V., C. G. Vassileva. 1997. Geochemistry of coals, coal ashes and combustion wastes from coal-fired power stations. - Fuel Processing Technology, 51, 19-45; https:// doi.org/10.1016/S0378-3820(96)01082-X.

Vassilev, S. V., C. G. Vassileva. 1998. Comparative chemical and mineral characterization of some Bulgarian coals. - Fuel Processing Technology, 55, 55-69; https://doi. org/10.1016/S0378-3820(97)00079-9.

Vassilev, S. V., M. G. Yossifova, C. G. Vassileva. 1994. Mineralogy and geochemistry of Bobov Dol coals, Bulgaria. - Intern. J. Coal Geol., 26, 185-213; https://doi. org/10.1016/0166-5162(94)90010-8.

Vassilev, S. V., G. M. Eskenazy, M. P. Tarassov, V. I. Dimov. 1995. Mineralogy and geochemistry of a vitrain lens with unique trace elements content from the Vulche Pole coal deposit, Bulgaria. - Geologica Balc., 25, 3-4, 111-124.

Vassilev, S. V., K. Kitano, C. G. Vassileva. 1997. Relations between ash yield and chemical and mineral composition of coals. - Fuel, 76, 3-8; https://doi.org/10.1016/S00162361(96)00181-0.

Vassilev, S. V., R. Menendez, D. Alvarez, M. Diaz-Somoano, M. R. Martinez-Tarazona. 2003. Phase-mineral and chemical composition of coal fly ashes as a basis for their multicomponent utilization. 1. Characterization of feed coals and fly ashes. - Fuel, 82, 1793-1811; https://doi.org/10.1016/ S0016-2361(03)00123-6.

Vassilev, S. V., C. G. Vassileva, D. Baxter, L. K. Andersen. 2010. Relationships between chemical and mineral composition of coal and their potential applications as genetic indicators. Part 1. Chemical characteristics. - Geologica Balc., 39, 3, 21-41.

Vatsev, M. 1979. Lithostratigraphy of the Neogene sedimentary rocks from the Gotse Delchev Basin. - Ann. l'école supérioure des min. et géol., 25, 1-géol., 103-115 (in Bulgarian with English abstract).

Vatsev, M. 1991. Lithostratigraphy of Neogene at Simitly and Brezhani graben (SW Bulgaria). - Ann. Univ. Mining and Geol., 37, 1-Geol., 23-38.

Vatsev, M. 1999. Lithostratigraphy of the Neogene in the Staniantsi Basin. - Ann. Univ. Mining and Geol., 42, 1-Geol., 35-43 (in Bulgarian with English abstract).

Vatsev, M. 2014. Contribution to the stratigraphy of the Oligocene-Lower Miocene sediments of the Bobovdol coalbearing Basin (South-Western Bulgaria). Part 1 - Lithostratigraphy of the Rupelian sediments. - Rev. Bulg. Geol. Soc., 75, 1-3, 47-62 (in Bulgarian with English abstract).

Vatsev, M. 2015. Contribution to the stratigraphy of the Oligocene-Lower Miocene sediments of the Bobovdol coal Basin (South-Western Bulgaria). Part 2 - Lithostratigraphy of the Chattian-Lower Miocene sediments. - Rev. Bulg. Geol. Soc., 76, 1, 5-21.

Vatsev, M., P. Bonev. 1994. Lithostratigraphy of the Neogene of the Kjustendil Basin (southwest Bulgaria). - Ann. Univ. Mining and Geol., 40, 1-Geol., 43-50 (in Bulgarian with English abstract). 
Vatsev, M., S. Juranov, S. Seferinov. 2011. Contribution to stratigraphy of the Eocene sediments of Padesh basin (SouthWestern Bulgaria). - C. R. Acad. Bulg. Sci., 64, 1, 81-90.

Voitkevich, G. V., L. Y. Kizil'shtein, Y. I. Kholodkhov. 1983. The Role of Organic Matter in Metal Concentration in the Earth's Crust. Moscow, Nedra, 154 p. (in Russian).

Ward, C. R. 1992. Mineral matter in triassic and tertiary lowrank coals from South Australia. - Intern. J. Coal Geol., 20, 185-208; https://doi.org/10.1016/0166-5162(92)90013-M.

Ward, C. R., D. Spears, C. A. Booth, I. Staton, L. W. Gurba. 1999. Mineral matter and trace elements in coals of the Gunnedah Basin, New South Wales, Australia. - Intern. J. Coal Geol., 40, 281-308; https://doi.org/10.1016/S01665162(99)00006-3.

Warwick, P. D., S. S. Crowley, L. F. Ruppert, J. Pontolillo. 1997. Petrography and geochemistry of selected lignite beds in the Gibbons Creek mine (Manning Formation, Jackson Group, Paleocene) of east-central Texas. - Intern. J. Coal Geol., 34, 307-326; https://doi.org/10.1016/S01665162(97)00028-1.

Yanev, S., D. Tchounev, T. Tzankov, D. Tronkov, I. Sapunov, P. Tchoumatchenko, I. Haidoutov, P. Petrov, T. Nikolov, R. Dimitrova, R. Marinova, I. Rusanov, Y. Gercheva. 1995. Explanatory Note to the Geological Map of Bulgaria on Scale 1:100 000. Sofia Map Sheet. Sofia, Committee of Geology and Mineral Resources, Geology \& Geophysics Corp., 133 p. (in Bulgarian with English abstract).

Yossifova, M. G. 2007. Mineral and inorganic chemical composition of the Pernik coal, Bulgaria. - Intern. J. Coal Geol., 72, 268-292; https://doi.org/10.1016/j.coal.2007.03.001.

Yossifova, M. G. 2014. Petrography, mineralogy and geochemistry of Balkan coals and their waste products. - Intern. J. Coal Geol., 122, 1-20; https://doi.org/10.1016/j. coal.2013.12.007.

Yossifova, M., D. Dimitrova. 2013. Concentration trend of trace elements in coal, partings and vegetation from the Maritza East Coal region, Bulgaria. - Proceedings volume 4, 12th Biennail SGA Meeting. 12-15 August 2013, Uppsala, Sweden, Erik Jonsson 4, 1878-1881.
Yossifova, M., C. Lerouge, Y. Deschamps. 2009. Mineral matter and trace elements in the Vulche Pole coal, Bulgaria. - GeoLines, 22, 87-94.

Yudovich, Y. E., M. P. Ketris. 2002. Inorganic Matter in Coal. Ekaterinburg, Uro RAN, 421 p. (in Russian).

Zagorčev, I., R. Marinova, D. Tchounev, P. Tchoumatchenko, I. Sapunov, S. Yanev. 1994. Explanatory Note to the Geological Map of Bulgaria on Scale 1:100 000. Pernik Map Sheet. Sofia, Committee of Geology and Mineral Resources, Geology \& Geophysics Corp., 92 p. (in Bulgarian with English abstract).

Zagorcev, I., V. Kostadinov, D. Tchounev, R. Dimitrova, I. Sapunov, P. Tchoumatchenco, S. Yanev. 1995. Explanatory Note to the Geological Map of Bulgaria on Scale 1:100 000. Vlasotnice and Breznik Map Sheets. Sofia, Committee of Geology and Mineral Resources, Geology \& Geophysics Corp., 107 p. (in Bulgarian with English abstract).

Zhang, B., J. Chen, J. Sha, S. Zhang, J. Zeng, P. Chen, D. Yao, W. Liu, X. Wang, P. Zhang, G. Liu, X. Li. 2020. Geochemistry of coal thermally-altered by igneous intrusion: A case study from the Pansan Coal Mine of Huainan Coalfield, Anhui, Eastern China. - J. Geochem. Explor., 213, 106532; https://doi.org/10.1016/j.gexplo.2020.106532.

Zhao, C., B. Liu, L. Xiao, Y. Li, S. Liu, Z. Li, B. Zhao, J. Ma, G. Chu, P. Gao, Y. Sun. 2017. Significant enrichment of $\mathrm{Ga}, \mathrm{Rb}, \mathrm{Cs}, \mathrm{REEs}$ and $\mathrm{Y}$ in the Jurassic No. 6 coal in the Iqe Coalfield, northern Qaidam Basin, China - A hidden gem. - Ore Geol. Rev., 83, 1-13; https://doi.org/10.1016/j. oregeorev.2016.12.012.

Zhao, Q., Y. Niu, Z. Xie, K. Zhang, J. Zhou, S. Arbuzov. 2020. Geochemical characteristics of elements in coal seams 41 and 42 of Heshan Coalfield, South China. - Energy Exploration \& Exploitation, 38, 137-157; https://doi. org/10.1177/0144598719886188.

Životić, D., O. Cvetković, P. Vulić, I. Gržetić, V. Simić, K. Ilijević, B. Dojčinović, S. Erić, B. Radić, S. Stojadinović, S. Trifunović. 2019. Distribution of major and trace elements in the Kovin lignite (Serbia). - Geologia Croatica, 72, 51-79; https://doi.org/10.4154/gc.2019.06.

Постьпила на 18.06.2021 г., приета за печат на 13.09.2021 г. Отговорни редактори Борис Вълчев, Йочо Янев 